\title{
Insulin receptor substrate gene polymorphisms are associated with metabolic syndrome but not with its components
}

\author{
Fulden Sarac ${ }^{1^{\star}}$, Afig Berdeli $^{2}$, Sefa Sarac $^{3}$, Sumru Savas $^{1}$, Merve Atan $^{2}$, Fehmi Akcicek $^{1}$ \\ ${ }^{1}$ Department of Geriatrics Medicine, Medical Faculty, Ege University, Izmir, Turkey; \\ *Corresponding Author: fuldensarac@yahoo.com \\ ${ }^{2}$ Department of Moleculer Medicine Laboratory, Medical Faculty, Ege University, Izmir, Turkey \\ ${ }^{3}$ Department of Cardiology, Atatürk Training and Research Hospital, Izmir, Turkey
}

Received 9 October 2013; revised 3 November 2013; accepted 10 November 2013

Copyright (C) 2013 Fulden Sarac et al. This is an open access article distributed under the Creative Commons Attribution License, which permits unrestricted use, distribution, and reproduction in any medium, provided the original work is properly cited.

\section{ABSTRACT}

Aim: Metabolic syndrome (MetS) is a major risk factor for both diabetes mellitus and cardiovascular disease (CVD). The aims of the study were 1) to investigate the insulin receptor substrate-1 (IRS-1) and insulin receptor substrate-2 (IRS-2) gene polymorphisms in patients with MetS and 2) to examine the relationships between gene polymorphisms and components of MetS. Patients \& Methods: The study population included 100 patients with MetS and 30 patients without MetS as control group. Metabolic syndrome (MS) was defined as in ATP III. Entire coding exons of IRS-1 and IRS-2 genes were amplified by polymerase chain reaction (PCR). Insulin resistance (IR) was estimated using the homeostasis model assessment (HOMA). Results: In patients with MetS, 34 (34\%), had G972R (rs1801278) gene polymorphism and 66 (66\%) had no nucleotide substitutions at the IRS-1 gene $(p<0.0001)$. As for the IRS-2 gene, $18.0 \%$ of the patients were heterozygous and $11.0 \%$ were homozygous for the G1057D mutation, $2.0 \%$ were heterozygous for the P1031P and P1033PG1057 mutations, $17.0 \%$ were heterozygous for P1033P, 3.0\% were homozygous for P1033P and 5\% were heterozygous for the G 1067D and P1033P mutations in patients with MetS $(p=0.0001)$. However, none of the control subjects had nucleotide substitutions in the IRS1 and IRS-2 genes. There were no correlations between IRS-1/IRS-2 gene polymorphisms and metabolic syndrome components such as waist circumference, blood pressure, triglyceride, HDL-
Cholesterol, LDL-Cholesterol and HOMA-IR levels. Conclusion: Insulin receptor substrate-1 and 2 gene polymorphisms were associated with metabolic syndrome but not its components.

Keywords: Metabolic Syndrome; Insulin Receptor Substrat-1 Gene; Insulin Receptor Substrat-2 Gene

\section{INTRODUCTION}

Metabolic syndrome (MetS) is one of the fastest growing health problems worldwide. It is a major risk factor for both diabetes mellitus [1] and cardiovascular disease (CVD) [2]. The etiology is complex, determined by the interplay of both genetic and environmental factors [3]. It is characterized by the clustering of multiple metabolic abnormalities, including abdominal obesity, hypertension, dyslipidemia, insulin resistance, and impaired glucose tolerance. Candidate gene studies have identified linkage between MetS and a number of genes, such as PPARgamma, adiponectin, CD36, and beta adrenergic receptors [2]. Recently, De la Cruz-Mosso et al. [4] suggested that the -844 G/A PAI-1 polymorphism was related with the risk of developing metabolic syndrome, obesity and atherogenic dyslipidemia, and the HindIII C/G PAI-1 polymorphism was associated with the increase of total cholesterol levels in Mexican children. In addition to these genes, in a previous IRS proteins [5-8] have been identified, but only IRS-1 and IRS-2 are thought to participate in the regulation of glucose homeostasis [9-11]. In a previous study, Baroni et al. [12] demonstrated the association of the G972R variant of the IRS-1 gene with reduced insulin sensitivity in obese subjects, and indicate a possible interaction between the IRS-1 variant and obesity in worsening of in- 
sulin sensitivity. Likewise, Arg972 polymorphism in IRS- 1 was observed in $15.8 \%$ of the type 2 diabetic patients and $12.9 \%$ of controls in a Turkish population [13]. In addition to the IRS-1 gene, a number of polymerphisms have been identified in the IRS-2 gene, the most common of which is represented by Gly1057Asp substitution [14]. And also, the G972R polymorphism of the IRS-1 gene was associated with insulin resistance, salt sensitivity and non-dipper hypertension [15]. However, not many studies exist concerned with the relationships between IRS-1 or IRS-2 gene polymorphisms and components of MetS. Therefore, the aims of the study were 1) to investigate the insulin receptor substrate-1 (IRS-1) and insulin receptor substrate-2 (IRS-2) gene polymorphisms in patients with MetS and 2) to examine the relationships between gene polymorphisms and components of MetS.

\section{METHODS}

\subsection{Study Population}

The study population included 100 patients with metabolic syndrome (MetS) (71 females, 29 males, mean age $50.1 \pm 8.8 \mathrm{yrs}$, BMI $\left.34.4 \pm 5.8 \mathrm{~kg} / \mathrm{m}^{2}\right)$. Thirty one subjects without MetS (5 males, 26 females, mean age $49.4 \pm 6.4 \mathrm{yrs}$, BMI $33.5 \pm 4.8 \mathrm{~kg} / \mathrm{m}^{2}$ ) were enrolled in the study as the control group. The local ethics committee approved the study and all subjects gave informed consent. Metabolic syndrome (MS) was defined as in ATP III [16].

Anthropometric measurements were made in all subjects. A two point bioelectrical impedance apparatus calibrated for adults (Tanita TBF 300, TANITA Corp.) was used to measure the percentage body fat (\%BF) and fat mass.

Habitual alcohol consumption and smoking were inquired with the following two questions: "Do you drink alcohol at least once a month? Yes/No".

"Do you smoke? Yes/No." If Yes, smokers were classified into two categories as ex-smokers and non-smokers [17].

\subsection{Molecular Analysis}

\subsubsection{IRS1 Gene Polymorphism Genotyping}

Two mililiter whole blood samples were collected into EDTA-anticoagulated tubes by the standard vein puncture method. Genomic DNA was extracted from EDTAanticoagulated whole blood samples employing the QIAmp Blood DNA mini-kit (Qiagen, Hilden, Germany) following manufacturer's instructions. DNA concentration was determined by the Nano Drop digital spectroscopy according to the manufacturer's instructions and diluted to $100 \mathrm{ng} / \mu \mathrm{l}$.

\subsubsection{Polymerase Chain Reaction (PCR) and Enzyme Digest}

IRS1 gene polymorphism was genotyped be the method of Baroni et al. [18] who had designed primers spanning a region of $198 \mathrm{bp}$ using the following primers: forward 5'-GCTTTCCACAGCTCACCTTC-3' and reverse 5'-GGTAGGCCTGCAAATGCTA-3'.

PCR conditions: Amplification was carried out on a GeneAmp PCR System 9700 ( PE Applied Biosystems, Foster City, CA, USA) in a $25 \mu 1$ reaction mixture in 0.2 $\mathrm{ml}$ thin-wall PCR strip tubes (Axygen Scientific, Inc., CA, USA) containing $1 \mu \mathrm{l}$ genomic DNA solution, Platinium Enhancer Buffer, $2.0 \mathrm{mmol} \mathrm{MgCl}_{2}, 50 \mu \mathrm{mol} / 1$ each of the dGTP, dATp, dTTP and dCTP (Promega, Madison, WI, USA), 5 pmol each forward and reverse primers and 1.0 U Platinium Taq polymerase (Invitrogen, Carlsbad, UK). The cycling conditions comprised a hot start at $95^{\circ} \mathrm{C}$ for $10 \mathrm{~min}$, followed by 35 amplification cycles at $95^{\circ} \mathrm{C}$ for $30 \mathrm{~s}, 55^{\circ} \mathrm{C}$ for $30 \mathrm{~s}$, and $72^{\circ} \mathrm{C}$ for $25 \mathrm{~s}$, followed by one elongation step at $72^{\circ} \mathrm{C}$ for $5 \mathrm{~min}$.

Digestion conditions: The amplified IRS-1 products were digested by SmaI (5.0 units) in a total volume of 20 $\mu 1$ containing NEBuffer 4 (New England Biolabs, Beverly, Ma, USA) for at least $2 \mathrm{~h}$ at $25^{\circ} \mathrm{C}$. The IRS-1 fragments (wild-type GG-171 and 27 bp; heterozygous GA198, 171 and 27 bp and homozygous AA-198 bp) were run on a $2 \%$ agarose gel containing Etidium Bromide and visualized under ultraviolet illumination.

\subsubsection{IRS2 Gene Polymorphism Genotyping}

Two mililiter whole blood samples were collected into EDTA-anticoagulated tubes by the standard vein puncture method. Genomic DNA was extracted from EDTAanticoagulated whole blood samples employing the QIAmp Blood DNA mini-kit (Qiagen, Hilden, Germany) following manufacturer's instructions. DNA concentration was determined by the NanoDrop digital spectroscopy according to the manufacturer's instructions and diluted to100 $\mathrm{ng} / \mu \mathrm{l}$.

\subsubsection{Polymerase Chain Reaction and Enzyme Digest}

IRS2 gene polymorphism was genotyped by the method of Lautier et al. Who had designed primers spanning a region of $198 \mathrm{bp}$ using the following primers: forward 5'-TCCTTGGACGGCCTCCTGT-3' and 5'-AA GGCCTCGACTCCCGACA-3' [18].

\subsubsection{Reverse Primers}

PCR conditions: Amplification was carried out on a GeneAmp PCR System 9700 (PE Applied Biosystems, Foster City, Ca, USA) in a $25 \mu 1$ reaction mixture in 0.2 $\mathrm{ml}$ thin-wall PCR strip tubes (Axygen Scientific Inc., CA, 
USA) containing $1 \mu \mathrm{l}$ genomic DNA solution, Platinium Enhancer Buffer, $2.5 \mathrm{mmol} \mathrm{MgCl}_{2}, 50 \mu \mathrm{mol} / \mathrm{l}$ each of the dGTP, dATp, dTTP and dCTP (Promega, Madison,WI, USA), 5 pmol each forward and reverse primers and 1.0 U Platinium Taq polymerase (Invitrogen, Carlsbad, UK). The cycling conditions comprised a hot start at $95^{\circ} \mathrm{C}$ for $10 \mathrm{~min}$, followed by 35 amplification cycles at $95^{\circ} \mathrm{C}$ for $30 \mathrm{~s}, 58^{\circ} \mathrm{C}$ for $30 \mathrm{~s}$, and $72^{\circ} \mathrm{C}$ for $25 \mathrm{~s}$, followed by one elongation step at $72^{\circ} \mathrm{C}$ for $5 \mathrm{~min}$.

\subsection{Biochemical Analysis}

Serum concentrations of glucose, triglyceride, total and HDL-Cholesterol were determined by enzymatic procedures. Serum insulin was measured by chemilumminance.

Insulin resistance (IR) was estimated using the homeostasis model assessment (HOMA) from fasting glucose and insulin concentrations using the following formula [19].

$$
H O M A-I R=\frac{(\text { fasting plasma insulin }[\mu \mathrm{U} / \mathrm{ml}]) \times(\text { fasting plasma glucose }[\mathrm{mmol} / \mathrm{l}])}{22.5}
$$

\subsection{Statistical Analysis}

Statistical analysis was performed using the SPSS for Windows (13.0) software package. Numerical variables were expressed as mean \pm standard deviation. The groups were compared using the Mann Whitney test. The relationships between metabolic syndrome risk and gene polymorphisms were evaluated using chi-square or Fisher's Exact test. Also, numerical demographic and biochemical parameters were evaluated using Mann Whitney test according to the gene polymorphisms in groups.

\section{RESULTS}

The characteristics and clinical findings of the study and control groups are shown in Table 1. Patients with MetS had higher mean values of waist and hip circumference, systolic and diastolic blood pressures than those

Table 1. Demographic characteristics of patients with metabolic syndrome and control were shown.

\begin{tabular}{cccc}
\hline Parameters & $\begin{array}{c}\text { Metabolic } \\
\text { syndrome } \\
(\mathbf{n = 1 0 0 )}\end{array}$ & $\begin{array}{c}\text { Control } \\
(\mathbf{n = 3 1 )}\end{array}$ & $\boldsymbol{p}$ \\
\hline Age (years) & $50.1 \pm 8.8$ & $49.4 \pm 6.4$ & 0.63 \\
Smokers, no (\%) & $45.0 \%$ & $9.0 \%$ & $0.03^{*}$ \\
Smoking pocket/year & $20.1 \pm 7.5$ & $10.1 \pm 2.8$ & $0.01^{*}$ \\
Alcohol consumption, no (\%) & $22.0 \%$ & $16.1 \%$ & $0.02^{*}$ \\
Body weight (kg) & $92.0 \pm 17.6$ & $91.0 \pm 8.5$ & 0.26 \\
Body Mass Index (kg/m $\left.{ }^{2}\right)$ & $34.4 \pm 5.8$ & $33.5 \pm 4.8$ & 0.83 \\
Fat mass $(\mathrm{kg})$ & $40.0 \pm 7.6$ & $39.5 \pm 5.1$ & 0.70 \\
\% Fat & $42.6 \pm 11.1$ & $40.7 \pm 8.8$ & 0.95 \\
\hline Waist circumference $(\mathrm{cm})$ & $105.6 \pm 18.2$ & $95.2 \pm 15.5$ & $0.001^{*}$ \\
Hip circumference $(\mathrm{cm})$ & $112.0 \pm 9.8$ & $101.1 \pm 9.0$ & $0.01^{*}$ \\
Systolic Blood Pressure $(\mathrm{mmHg})$ & $120.0 \pm 14.0$ & $110.0 \pm 17.1$ & $0.001^{*}$ \\
Diastolic Blood Pressure (mmHg) & $69.9 \pm 15.3$ & $62.1 \pm 14.8$ & $0.002^{*}$ \\
\hline
\end{tabular}

${ }^{*}$ Data are expressed as mean $\pm \mathrm{SD}$. of patients without MetS $(p=0.001, p=0.01, p=0.001$, $p=0.002$, respectively).

Among patients with MetS, $45.0 \%$ were smokers and $22.0 \%$ informed alcohol consumption. However, $9.0 \%$ of control subjects were smokers and only $16.1 \%$ of them consumed alcohol $(p=0.03, p=0.02)$.

Of 100 patients with MetS, $15(15 \%)$ had a history of cardiovascular disease, 49 (49\%) had dyslipidemia, 40 (40\%) had hypertension and 15 (15\%) had type 2 diabetes mellitus. In the control group, $2(6.4 \%)$ had a family history of cardiovascular disease, $7(22.5 \%)$ had dyslipidemia, $10(32.2 \%)$ had hypertension and 1 (3.2\%) had type 2 diabetes mellitus (Table 2).

In patients with MetS, 34 (34\%) patients had G972R (rs1801278) gene polymorphism and $66(66 \%)$ had no nucleotide substitution in the IRS-1 gene $(p<0.0001)$. As to the IRS-2 gene, 44 (44\%) had no nucletide substitution, 18 (18\%) had G1057D (rs1805097) heterozygous, $11(11.0 \%)$ had G1057D homozygous, 2 (2\%) had P1031P heterozygous/P1033PG1057 heterozygous, 17 (17.0\%) had P1033P heterozygous, 3 (3.0\%) had P1033P homozygous and $5(5 \%)$ had P1033P heterozygous/ G1067D heterzoygous polymorphisms in MetS $(p=$ $0.0001)$. However, none of control subjects had nucleotide substitutions in the IRS- 1 and IRS-2 genes.

There were statistically significantly differences for plasma levels of fasting insulin $(p=0.001)$, triglyceride $(p=0.001)$, LDL-Cholesterol $(p=0.001)$, and HOMAIR $(p=0.01)$, between the study and control groups (Table 3).

Demographic and biochemical parameters according to gene polymorphisms were shown in patients with MetS (Table 4). There were no associations between IRS-1 and IRS-2 gene polymorphisms and blood pressures, waist circumferences, fasting glucose, triglyceride and HDL-Cholesterol levels in patients with MetS ( $\mathrm{p}>$ $0.05)$.

\section{DISCUSSION}

Metabolic syndrome (MetS) is a consequence of mul- 
Table 2. Genetic variants of IRS-1 and IRS-2 genes were shown in women with and without metabolic syndrome.

\begin{tabular}{|c|c|c|c|c|}
\hline & & Metabolic syndrome $(\mathrm{n}=100)$ & Control $(\mathrm{n}=31)$ & $p$ values \\
\hline \multirow{2}{*}{ IRS-1 } & No nucleotide substitution & $66(66 \%)$ & $31(100 \%)$ & \multirow{2}{*}{$p<0.0001$} \\
\hline & G972R & $34(34 \%)$ & $0(0 \%)$ & \\
\hline \multirow{7}{*}{ IRS-2 } & No nucleotide substitution & $44(44 \%)$ & $31(100 \%)$ & \multirow{7}{*}{$p<0.0001$} \\
\hline & G1057D heterozygous & $18(18 \%)$ & $0(0 \%)$ & \\
\hline & G1057D homozyous & $11(11 \%)$ & $0(0 \%)$ & \\
\hline & P1031P heterozygous/P1033PG1057 heterozygous & $2(2 \%)$ & $0(0 \%)$ & \\
\hline & P 1033 P heterozygous & $17(17 \%)$ & $0(0 \%)$ & \\
\hline & P 1033 P homozygous & $3(3 \%)$ & $0(0 \%)$ & \\
\hline & P 1033P heterozygous/G 1057D heterozygous & $5(5 \%)$ & $0(0 \%)$ & \\
\hline
\end{tabular}

Table 3. Blood profiles of patients with metabolic syndrome and control were shown.

\begin{tabular}{cccc}
\hline & $\begin{array}{c}\text { Metabolic } \\
\text { syndrome } \\
(\mathbf{n}=\mathbf{1 0 0})\end{array}$ & $\begin{array}{c}\text { Control } \\
(\mathbf{n}=\mathbf{3 1})\end{array}$ & $\boldsymbol{p}$ \\
\hline Triglyceride $(\mathrm{mg} / \mathrm{dl})$ & $177.6 \pm 10.8$ & $133.6 \pm 27.3$ & $0.001^{*}$ \\
Total-Cholesterol $(\mathrm{mg} / \mathrm{dl})$ & $209.5 \pm 45.0$ & $199.0 \pm 29.0$ & 0.85 \\
LDL-Cholesterol $(\mathrm{mg} / \mathrm{dl})$ & $148.1 \pm 35.6$ & $101.3 \pm 122.3$ & $0.001^{*}$ \\
HDL-Cholesterol $(\mathrm{mg} / \mathrm{dl})$ & $45.3 \pm 7.2$ & $45.8 \pm 5.3$ & 0.37 \\
Fasting glucose $(\mathrm{mg} / \mathrm{dl})$ & $90.6 \pm 11.0$ & $89.5 \pm 8.4$ & 0.17 \\
Fasting insulin $(\mu \mathrm{U} / \mathrm{ml})$ & $9.9 \pm 3.7$ & $7.1 \pm 0.7$ & $0.001^{*}$ \\
HOMA-IR & $2.2 \pm 0.89$ & $1.7 \pm 0.77$ & $0.01^{*}$ \\
\hline
\end{tabular}

*Data are expressed as mean $\pm \mathrm{SD}$. HOMA-IR $=$ Homeostasis model assessment-insulin resistance; LDL $=$ Low-density lipoprotein; HDL $=$ Highdensity lipoprotein.

tiple gene-environment interactions. Several potential candidate genes have been suggested according to their biological relevance, such as genes in systems of energy balance, nutrient partitioning, lipid and insulin metabolism, lipolysis, thermogenesis, fuel oxidation and glucose uptake in skeletal muscle. Many of these genes have been associated with MetS in various ethnic populations [2]. Although many different genes have been proposed as diabetogenes, this study focused on the IRS-1 and IRS-2 genes. These are the major substrates participating in insulin action in skeletal muscle. Defects in IRS-1 or IRS-2 which are major substrates tiyrosine phosphorylation characterizes insulin resistance associated with diabetes [20]. To our knowledge, insulin resistance is a key player in the pathophysiology of the MetS and has even been postulated as its underlying cause [21]. In general, the stigmata of the MetS are significantly associated with insulin resistance [22]. In addition, certain genetic variants have been observed to increase or decrease the risk of developing the entire syndrome [23]. The present study showed that there was statistically significant associations of IRS-1 and IRS-2 gene polymorphisms with MetS. However, no relationships between gene polymorphisms and components of MetS were found.

Several polymorphisms of the IRS-1 gene have been identified and studied with regard to their influence on insulin action [24]. Ura et al. [25] reported that three genetic variants of IRS-1 exist (Pro170Arg; Met209Thr; Ser809Phe) in Japanese patients with NIDDM. In another study [12], it was reported that Ala512Pro, Ser892Gly in IRS-1 gene were rare and Gly972Arg in IRS-1 gene was more common in Turkish population but might not be a major determinant of genetic susceptility to type 2 diabetes. However, Ranjith et al. [26] reported that their findings did not support a role for any of the polymorphic variant alleles such as IRS-I G972R, PPARgamma P12A, KCNJ11 E23K, and TNF-alpha -308G/A genes examined in the etiology of insulin resistance reinforce the notion of a multifactorial etiology for the MetS. In the present study, we found 34.0\% G972R gene polymorphism in IRS-1 gene in MetS. However, none of the controls had nucleotide substitution in IRS-1 gene. Thus, we can conclude that G972R in IRS-1 gene is associated with metabolic syndrome.

Insulin receptor substrate-2, like IRS-1, is thought to be involved in insulin signaling and glucose intolerance [27-29]. In humans, a number of polymorphisms have been identified in the IRS2 gene, including Gly1057Asp variant that occured with an allelic frequency of $34 \%$ [30]. In another study, Attaoua et al. [31] suggested an independent association of IRS-2 variant with insulin resistance. In the present study, at the IRS-2 gene $18.0 \%$ of the patients were heterozygous and $11.0 \%$ were homozygous for the G1057D mutation, $2.0 \%$ were heterozygous for the P1031P and P1033PG1057 mutations, $17.0 \%$ were heterozygous for P1033P, 3.0\% were homozygous for P1033P and 5\% were heterozygous for the 
Table 4. Demographic and biochemical parameters were shown according to insulin receptor substrat-1 (IRS-1) and insulin receptor substrat-2 (IRS-2) genes in patients with metabolic syndrome.

\begin{tabular}{|c|c|c|c|c|c|c|}
\hline & $\begin{array}{c}\text { IRS-1 } \\
\text { polymorphism (-) } \\
(\mathrm{n}=66)\end{array}$ & $\begin{array}{c}\text { IRS-1 } \\
\underset{(n=34)}{\text { polymorphism }(+)} \\
(n=34\end{array}$ & $p$ & $\begin{array}{c}\text { IRS-2 } \\
\text { polymorphism (-) } \\
(\mathrm{n}=42)\end{array}$ & $\begin{array}{c}\text { IRS-2 } \\
\text { polymorphism }(+) \\
(\mathrm{n}=58)\end{array}$ & $p$ \\
\hline Age & $49.7 \pm 8.7$ & $48.7 \pm 6.1$ & 0.81 & $48.8 \pm 8.2$ & $50.36 \pm 8.9$ & 0.61 \\
\hline Body weight $(\mathrm{kg})$ & $93.0 \pm 17.8$ & $83.9 \pm 7.7$ & 0.32 & $92.7 \pm 17.5$ & $92.6 \pm 17.6$ & 0.32 \\
\hline Body Mass Index $\left(\mathrm{kg} / \mathrm{m}^{2}\right)$ & $34.9 \pm 6.4$ & $30.0 \pm 3.4$ & 0.73 & $34.1 \pm 6.1$ & $35.1 \pm 6.5$ & 0.07 \\
\hline Waist circumference $(\mathrm{cm})$ & $105.8 \pm 10.3$ & $100.2 \pm 3.3$ & 0.20 & $106.3 \pm 10.4$ & $105.1 \pm 10.1$ & 0.20 \\
\hline Hip circumference $(\mathrm{cm})$ & $112.2 \pm 9.9$ & $105.5 \pm 5.1$ & 0.20 & $113.0 \pm 9.9$ & $111.2 \pm 9.8$ & 0.26 \\
\hline Fat mass (kg) & $39.8 \pm 9.2$ & $41.1 \pm 5.8$ & 0.90 & $41.9 \pm 14.8$ & $40.8 \pm 26.1$ & 0.70 \\
\hline$\%$ fat & $41.4 \pm 7.1$ & $42.4 \pm 4.2$ & 0.80 & $40.8 \pm 5.0$ & $40.1 \pm 4.1$ & 0.35 \\
\hline Systolic blood pressure (mmHg) & $126.6 \pm 19.5$ & $127.5 \pm 6.4$ & 0.60 & $123.7 \pm 15.0$ & $128.7 \pm 21.6$ & 0.60 \\
\hline Diastolic blood pressure (mmHg) & $70.1 \pm 15.6$ & $66.2 \pm 4.7$ & 0.92 & $69.0 \pm 13.0$ & $70.26 \pm 16.4$ & 0.92 \\
\hline Triglyceride (mg/dl) & $178.2 \pm 61.3$ & $163.7 \pm 23.3$ & 0.88 & $179.8 \pm 68.8$ & $178.0 \pm 53.8$ & 0.88 \\
\hline Total-cholesterol (mg/dl) & $210.0 \pm 48.1$ & $198.5 \pm 40.0$ & 0.67 & $200.5 \pm 47.1$ & $215.1 \pm 44.0$ & 0.67 \\
\hline LDL-cholesterol (mg/dl) & $149.0 \pm 36.8$ & $150.0 \pm 41.8$ & 0.95 & $135.5 \pm 33.7$ & $158.8 \pm 36.1$ & 0.95 \\
\hline HDL-cholesterol (mg/dl) & $45.2 \pm 7.3$ & $45.5 \pm 7.2$ & 0.70 & $46.2 \pm 8.1$ & $44.54 \pm 6.4$ & 0.70 \\
\hline Fasting glucose (mg/dl) & $90.4 \pm 10.7$ & $95.5 \pm 2.8$ & 0.64 & $91.8 \pm 13.4$ & $89.7 \pm 9.0$ & 0.64 \\
\hline Fasting insulin $(\mu \mathrm{U} / \mathrm{ml})$ & $9.9 \pm 3.8$ & $10.2 \pm 3.2$ & 0.78 & $10.1 \pm 3.3$ & $9.8 \pm 4.0$ & 0.78 \\
\hline HOMA-IR & $2.2 \pm 20.9$ & $2.40 \pm 0.7$ & 0.49 & $2.30 \pm 0.8$ & $2.17 \pm 0.9$ & 0.49 \\
\hline
\end{tabular}

${ }^{*}$ Data are expressed as mean \pm SD. Abbreviations: HOMA-IR $=$ Homeostasis model assessment-insulin resistance; LDL $=$ Low-density lipoprotein; HDL $=$ High-density lipoprotein.

G 1067D and P1033P mutations in patients with MetS. However, none of the controls had nucleotide substitutions in IRS-2 gene.

Clinical studies [32,33] have shown that genetic variant in IRS-1 is associated with reduced insulin sensitivity. Likewise, the IRS1 gene contains polymorphisms located at codon 972 (BstNI) which has been associated with type 2 diabetes mellitus and insulin resistance. Moreover, earlier observation has indicated that the presence of a mutated IRS-1 gene is associated with dyslipidemia [34]. Recently, it was reported that rs2289046 polymorphism at the IRS2 gene locus might influenced insulin sensitivity by interacting with certain plasma fatty acids in MetS subjects [35]. In another study, Thomas et al. [36] suggested that an insulin receptor gene polymorphism was associated with diastolic blood pressure in Chinese subjects with components of the MetS. Similarly, it was suggested that a putative role of IGF1R variants in individual susceptibility to metabolic syndrome-related phenotypes, in particular on the risk of having insulin resistance and arterial hypertension [37]. In the present study, we didn't find any relationships between IRS-1 and IRS-2 gene polymorphisms and components of MetS such as blood pressures, waist circumferences, fasting glucose, triglyceride and HDL-Cholesterol levels.

\section{CONCLUSION}

In summary, insulin receptor substrate-1 and insulin receptor substrate- 2 gene polymorphisms are related to metabolic syndrome, but not its components.

\section{REFERENCES}

[1] Haffner, S.M., Valdez, R.A, Hazuda, H.P., Mitchell, B.D., Morales, P.A. and Stern, M.P. (1992) Prospective analysis of the insulin-resistance syndrome (syndrome X). Diabetes, 41, 715-722.

http://dx.doi.org/10.2337/diab.41.6.715

[2] Qing, S., Shaoshan, S.W. and Zafari, A.M. (2006) Genetics of the metabolic syndrome. Hospital Physician, 5161.

[3] Goodyear, L.J., Giorgino, F., Sherman, L.A., Carey, J., Smith, R.J. and Dohm, G.L. (1995) Insulin receptor phosphorylation, insulin receptor substrate-1 phosphorylation, and phosphatidylinositol 3-kinase activity are decreased in intact skeletal muscle strips from obese subjects. Journal of Clinical Investigation, 95, 2195-2204.

http://dx.doi.org/10.1172/JCI117909 
[4] De la Cruz-Mosso, U., Muñoz-Valle, J.F., Salgado-Goytia, L., García-Carreón, A., Illades-Aguiar, B., CastañedaSaucedo, E. and Parra-Rojas, I. (2012) Relationship of metabolic syndrome and its components with $-844 \mathrm{G} / \mathrm{A}$ and HindIII C/G PAI-1 gene polymorphisms in Mexican children. BMC Pediatrics, 29, 41.

http://dx.doi.org/10.1186/1471-2431-12-41

[5] Bjornholm, M., Kawano, Y., Lehtihet, M. and Zierath, J. R. (1997) Insulin receptor substrate-1 phosphorylation and phosphatidylinositol 3-kinase activity in skeletal muscle from NIDDM subjects after in vivo insulin stimulation. Diabetes, 46, 524-527.

http://dx.doi.org/10.2337/diab.46.3.524

[6] Carvalho, E., Jansson, P.A., Axelsen, M., Eriksson, J.W., Huang, X., Groop, L., Rondinone, C., Sjostrom, L. and Smith, U. (1999) Low cellular IRS 1 gene and protein expression predict insulin resistance and NIDDM. FASEB Journal, 13, 2173-2178.

[7] Krook, A., Bjornholm, M., Galuska, D., Jiang, X.J., Fahlman, R., Myers Jr., M.G., Wallberg-Henriksson, H. and Zierath, J.R. (2000) Characterization of signal transduction and glucose transport in skeletal muscle from type 2 diabetic patients. Diabetes, 49, 284-292. http://dx.doi.org/10.2337/diabetes.49.2.284

[8] Zierath, J.R., Krook, A. and Wallberg-Henriksson, H. (2000) Insulin action and insulin resistance in human skeletal muscle. Diabetologia, 43, 821-835. http://dx.doi.org/10.1007/s001250051457

[9] White, M.F., Maron, R. and Kahn, C.R. (1985) Insulin rapidly stimulates tyrosine phosphorylation of a $\mathrm{Mr}-$ 185,000 protein in intact cells. Nature, 318, 183-186. http://dx.doi.org/10.1038/318183a0

[10] White, M.F. and Kahn, C.R. (1994) The insulin signaling system. Journal of Biological Chemistry, 269, 1-4.

[11] Lavan, B.E., Lane, W.S. and Lienhard, G.E. (1997) The $60-\mathrm{kDa}$ phosphotyrosine protein in insulin-treated adipocytes is a new member of the insulin receptor substrate family. Journal of Biological Chemistry, 272, 1143911443. http://dx.doi.org/10.1074/jbc.272.34.21403

[12] Baroni, M.G., Leonetti, F., Sentinelli, F., Romeo, S., Filippi, E., Fanelli, M., Ribaudo, M.C., Zappaterreno, A., Fallarino M. and Di Mario, U. (2004) The G972R variant of the insulin receptor substrate-1 (IRS-1) gene is associated with insulin resistance in "uncomplicated" obese subjects evaluated by hyperinsulinemic-euglycemic clamp. Journal of Endocrinological Investigation, 27, 754-759.

[13] Orkunoglu Suer, F.E., Mergen, H., Bolu, E. and Ozata, M. (2005) Molecular scanning for mutations in the insulin receptor substrate-1 (IRS-1) gene in Turkish with type 2 diabetes mellitus. Endocrine Journal, 52, 593-598. http://dx.doi.org/10.1507/endocrj.52.593

[14] Mazzoccoli, G., Dagostino, M.P., Fontana, A., Grandone, E., Favuzzi, G., Tiscia, G., Margaglione, M., de Matthaeis, A., Greco, A. and Vendemiale, G. (2012) Influence of the Gly1057Asp variant of the insulin receptor substrate 2 (IRS2) on insulin resistance and relationship with epicardial fat thickness in the elderly. Experimental Gerontology, 47, 988-893.

http://dx.doi.org/10.1016/j.exger.2012.09.005
[15] Dziwura, J., Bińczak-Kuleta A., Miazgowski, T., Ziemak J. and Widecka, K. (2011) The associations between G972R polymorphism of the IRS-1 gene, insulin resistance, salt sensitivity and non-dipper hypertension. $\mathrm{Hy}$ pertension Research, 34, 1082-1086. http://dx.doi.org/10.1038/hr.2011.80

[16] Ford, E.S., Giles, W.H. and Dietz, W.H. (2002) Prevalence of the metabolic syndrome among US adults. JAMA, 287, 356-359. http://dx.doi.org/10.1001/jama.287.3.356

[17] Akbartabartoori, M., Lean, M.E. and Hankey, C.R. (2006) Smoking combined with overweight or obesity markedly elevates cardiovascular risk factors. European Journal of Preventive Cardiology, 13, 938-946.

[18] Lautier, C., El Mkadem, S.A., Renard, E., Brun, J.F., Gris, J.C., Bringer, J. and Grigorescu, F. (2003) Complex haplotypes of IRS2 gene are associated with severe obesity and reveal heterogeneity in the effect of Gly1057Asp mutation. Human Genetics, 113, 34-43.

[19] Mohn, A., Marcovecchio, M. and Chiarelli, F. (2006) Validity of HOMA-IR as index of insulin resistance in obesity. Journal of Pediatrics, 148, 565-566. http://dx.doi.org/10.1016/j.jpeds.2005.06.013

[20] Bouzakri, K., Zachrisson, A., Al-Khalili, L., Zhang, B.B., Koistinen, H.A., Krook, A., and Zierath, J.R. (2006) siRNA-based gene silencing reveals specialized roles of IRS-1/Akt2 and IRS-2/ Akt1 in glucose and lipid metabolism in human skeletal muscle. Cell Metabolism, 4, 89-96. http://dx.doi.org/10.1016/j.cmet.2006.04.008

[21] Hanley, A.J, Karter, A.J., Festa, A., D’Agostino Jr., R., Wagenknecht, L.E., Savage, P., Tracy, R.P., Saad, M.F. and Haffner, S. (2002) Factor analysis of metabolic syndrome using directly measured insulin sensitivity: The insulin resistance atherosclerosis study. Diabetes, 51, 2642-2647. http://dx.doi.org/10.2337/diabetes.51.8.2642

[22] Carr, D.B., Utzschneider, K.M., Hull, R.L., Kodama, K., Retzlaff, B.M., Brunzell, J.D., Shofer, J.B., Fish, B.E., Knopp, R.H. and Kahn, S.E. (2004) Intra-abdominal fat is a major determinant of the National Cholesterol Education Program Adult Treatment Panel III criteria for the metabolic syndrome. Diabetes, 53, 2087-2094. http://dx.doi.org/10.2337/diabetes.53.8.2087

[23] Phillips, C., Lopez-Miranda, J., Perez-Jimenez, F., McManus, R. and Roche, H.M. (2006) Genetic and nutrient determinants of the metabolic syndrome. Current Opinion in Cardiology, 21, 185-193.

http://dx.doi.org/10.1097/01.hco.0000221579.25878.11

[24] Almind, K., Bjorbaek, C. and Vestergaard, H. (1993) Amino acid polymorphisms of insulin receptor substrate-1 in noninsulin-dependent diabetes mellitus. Lancet, 342, 828-832.

http://dx.doi.org/10.1016/0140-6736(93)92694-O

[25] Ura, S., Araki, E., Kishikawa, H., Shirotani, T., Todaka, M., Isami, S., Shimoda, S., Yoshimura, R., Matsuda, K., Motoyoshi, S., Miyamura, N., Kahn C.R. and Shichiri, M. (1996) Molecular scanning of the insulin receptor substrate-1 (IRS-1) gene in Japanese patients with NIDDM: İdentification of five novel polymorphisms. Diabetologia, 39, 600-608. http://dx.doi.org/10.1007/BF00403308

[26] Ranjith, N., Pegoraro, R.J., Naidoo, D.P., Shanmugam, R. 
and Rom, L. (2008) Genetic variants associated with insulin resistance and metabolic syndrome in young Asian Indians with myocardial infarction. Metabolic Syndrome and Related Disorders, 6, 209-214. http://dx.doi.org/10.1089/met.2008.0023

[27] Withers, D.J., Burks, D.J., Towery, H.H., Altamuro, S.L., Flint, C.L. and White, M.F. (1999) Irs-2 coordinates Igf-1 receptor-mediated $\mathrm{h}$-cell development and peripheral insulin signaling. Nature Genetics, 23, 32-40. http://dx.doi.org/10.1038/12631

[28] Withers, D.J. (2001) Insulin receptor substrate proteins and neuroendocrine function. Biochemical Society Transactions, 29, 525-529.

http://dx.doi.org/10.1042/BST0290525

[29] Rojas, F.A., Hirata, A.E. and Saad, M.J. (2003) Regulation of insulin receptor substrate-2 tyrosine phosphorylation in animal models of insulin resistance. Endocrine, 21, 115-122. http://dx.doi.org/10.1385/ENDO:21:2:115

[30] Sesti, G., Federici, M., Hribal, M.L., Lauro, D., Sbraccia, P. and Lauro R. (2001) Defects of the insulin receptor substrate (IRS) system in human metabolic disorders. FASEB Journal, 15, 2099-2011. http://dx.doi.org/10.1096/fj.01-0009rev

[31] Attaoua, R., Ait El Mkadem, S., Lautier, C., Kaouache, S., Renard, E., Brun, J.F., Fedou, C., Gris, J.C., Bringer, J. and Grigorescu F. (2009) Association of the FTO gene with obesity and the metabolic syndrome is independent of the IRS-2 gene in the female population of Southern France. Diabetes \& Metabolism, 35, 476-483. http://dx.doi.org/10.1016/j.diabet.2009.07.002

[32] Clausen, J.O., Hansen, T., Bjorbaek, C., Echwald, S.M., Urhammer, S.A., Rasmussen, S., Andersen, C.B., Hansen, L., Almind, K., Winther, K., Haraldsdottir, J., BorchJohnsen, K. and Pedersen, O. (1995) Insulin resistance: İnteractions between obesity and a common variant of insulin receptor substrate-1. Lancet, 346, 397-402. http://dx.doi.org/10.1016/S0140-6736(95)92779-4

[33] Zang, Y., Wat, N., Stratton, I.M., Warren-Perry, M.G.,
Orho, M., Groop, L. and Turner, R.C. (1996) UKPDS19: Heterogeneity in NIDDM: separate contribution of IRS-1 and beta3-adrenergic-receptor mutations to insulin resistance and obesity respectively with no evidence for glycogen synthase gene mutations. Diabetologia, 39, 15051511. http://dx.doi.org/10.1007/s001250050605

[34] Sánchez-Corona, J., Flores-Martínez, S.E., MachorroLazo, M.V., Galaviz-Hernández, C., Morán-Moguel, M.C., Perea, F.J., Mújica-López, K.I., Vargas-Ancona, L., Laviada-Molina, H.A., Fernández, V., Pardío, J., Arroyo, P., Barrera, H. and Hanson, R.L. (2004) Polymorphisms in candidate genes for type 2 diabetes mellitus in a Mexican population with metabolic syndrome findings. Diabetes Research and Clinical Practice, 63, 47-55. http://dx.doi.org/10.1016/j.diabres.2003.08.004

[35] Perez-Martinez, P., Delgado-Lista, J., Garcia-Rios, A., Tierney, A.C., Gulseth, H.L., Williams, C.M., Karlström, B., Kieć-Wilk, B., Blaak, E.E., Helal, O., Saris, W.H., Defoort, C., Drevon, C.A., Lovegrove, J.A., DembinskaKieć, A., Riserus, U., Roche, H.M. and Lopez-Miranda, J (2012) Insulin receptor substrate-2 gene variants in subjects with metabolic syndrome: Association with plasma monounsaturated and n-3 polyunsaturated fatty acid levels and insulin resistance. Molecular Nutrition \& Food Research, 56, 309-315. http://dx.doi.org/10.1002/mnfr.201100504

[36] Thomas, G.N., Tomlinson, B., Chan, J.C., Lee, Z.S., Cockran, C.S. and Critchley, J.A (2000) An insulin receptor gene polymorphism is associated with diastolic blood pressure in Chinese subjects with components of the metabolic syndrome. American Journal of Hypertension, 13, 745-752. http://dx.doi.org/10.1016/S0895-7061(00)00265-X

[37] Sookoian, S., Gianotti, T.F., Gemma, C., Burgueño, A.L. and Pirola C.J (2010) Role of genetic variation in insulinlike growth factor 1 receptor on insulin resistance and arterial hypertension. Journal of Hypertension, 28, 11941202. 